\begin{tabular}{|c|c|}
\hline \multicolumn{2}{|c|}{ PublisherInfo } \\
\hline PublisherName & Palgrave Macmillan UK \\
\hline PublisherLocation & London \\
\hline PublisherImprintName & Palgrave Macmillan \\
\hline
\end{tabular}

\title{
The treatment of pensions in the National Accounts
}

\begin{tabular}{|l|l|l||}
\hline \multicolumn{2}{|c|}{ ArticleInfo } \\
\hline \hline ArticleDOI & $:$ & $10.1057 /$ palgrave.elmr.1410153 \\
\hline \hline ArticleCategory & $:$ & Feature \\
\hline \hline ArticleFirstPage & $:$ & 24 \\
\hline \hline ArticleLastPage & $:$ & 30 \\
\hline \hline & & RegistrationDate $: 2007-10-19$ \\
ArticleHistory & $:$ & OnlineDate $\quad$ 2007-10-19 \\
\hline \hline ArticleCopyright & $:$ & Crown copyright2007 \\
\hline \hline
\end{tabular}




\section{Explains the important concepts and principles that apply and how} pension schemes affect key statistics.

This article explains the important concepts and principles that apply in the National Accounts with regard to pensions. The impact of different types of pension schemes in the sector accounts is described (concentrating on the household sector), and the different ways in which pension schemes affect key statistics such as gross domestic product, gross disposable income and the household saving ratio are discussed.

\section{Misc}

The Full Text of this article can be found on the National Statistics website (http://www.statistics.gov.uk/elmr/10_07/downloads/elmr_oct07_rahman.pdf). 